\title{
The Effect of Business Planning and Record on Entrepreneur Success
}

DOI: https://doi.org/10.47175/rissj.v2i3.261

\section{| Formaida Tambunan ${ }^{1}$ |}

${ }^{1}$ Faculty of Economics and Social Sciences, Universitas Sari Mutiara Indonesia, Medan, Indonesia

*formaidatambunans@yahoo. com

\begin{abstract}
The problem that has always been in the government's spotlight is the low number of jobs, so the solution is entrepreneurship. Many food and beverage business people ignore business planning and recording so that it has an impact on the slow and even undeveloped business they run. Therefore, someone who is an entrepreneur needs a business plan and records in order to achieve success in entrepreneurship. The purpose of this study was to determine "The Influence of Business Planning and Records on Entrepreneurial Success. This research is an associative quantitative study with the population being all food and beverage entrepreneurs in Tanjung Rejo Village and the sample is a total population of 57 respondents. The research instrument used was a questionnaire and analyzed using multiple linear regression. The results show that business planning and records have an effect on entrepreneurial success. In connection with the results of this study, it is recommended to all people who want to be entrepreneurs and especially entrepreneurs to always make good plans and keep records of every business activity that is carried out.

KEYWORDS

planning; business records; entrepreneurial success.
\end{abstract}

\section{INTRODUCTION}

The problem that is always in the government's spotlight is the lack of employment opportunities to overcome unemployment so that it has an impact on the country's economy. The number of job seekers is more than the number of existing job vacancies. Therefore, to overcome this, of course one must take another alternative in order to be able to produce something that is beneficial for himself and also for others and the solution is entrepreneurship. But to be a successful entrepreneur is not as easy as many people think. There are various challenges that must be faced by every entrepreneur, from small things to big things. If this cannot be planned properly, then an entrepreneur will not be successful in entrepreneurship. Entrepreneurial success can be determined through the development of capital or assets. There are several opinions and research results which state that someone who is an entrepreneur needs the role of parents as founders (Wiratna and Tambunan, 2017), self-confidence and strong determination (Tambunan 2018), adversity question (Tambunan, 2020), business planning and records. where the planning referred to in this case is the vision and mission, short-term and long-term strategies, operations, products, information technology, while in the case of business records it is defined to determine the extent of the business being carried out such as sales records, finances (Hendro, 2011), The next step is to require patience, venture capital and others in running a business where some of these things are referred to as factors that influence the success of entrepreneurship. Through good planning will help an entrepreneur determine priorities in entrepreneurship. A business plan can set the course of the business in 
accordance with the goals that have been planned from the start. Likewise, in running entrepreneurship, it is necessary to have a record that can monitor all these business activities. Business records can provide an overview of the development or running of the business, the entry or exit of a product being sold and others. Recording also has an important role and provides benefits for anyone who is an entrepreneur. Through recording, we can estimate the price of the products to be sold and can control each inventory of the products to be sold.

But the fact is that many food and beverage business people ignore the planning and recording of the business so that it has an impact on the slow and even undeveloped business being run. This can also be seen from several food and beverage business actors in the Tanjung Rejo Village area who did not make a plan at first when they started their business and even during their business activities did not record. As a result, some do not know the extent of the business activities carried out so that they are unable to develop their business. By looking at the description above, it is necessary to conduct a research entitled "The Influence of Business Planning and Records on Entrepreneurial Success".

\section{RESEARCH METHODS}

This research is an associative quantitative research conducted from March to June 2021 with a population of all entrepreneurs in Tanjung Rejo Village as many as 57 food and beverage entrepreneurs and the research sample is a total population of 57 respondents. To obtain the required data, research instruments were used using a questionnaire with a Likert scale of 4 answers. The data were analyzed using multiple linear regression analysis. To answer the research hypothesis, the $t$ test and $F$ test were used at a significant level of $95 \%$. Before the data is analyzed to answer the research hypothesis, a prerequisite test is first carried out.

\section{RESULTS AND DISCUSSION}

After collecting and processing the data, it was analyzed and the following results were obtained:

1. Validity and Reliability Test

Based on the results of the validity test, it is known that all research instruments on planning variables, business records and entrepreneurial success stated that all items were valid, while the reliability test results obtained the results of Cronbach's alpha value on the planning variable $=0.889$, the business record variable $=0.858$ and the entrepreneurial success variable $=0.728$ more greater than 0.60 so it can be stated that the three variables are reliable .

2. Prerequisite Test (Classic Assumption Test)

Based on the results of the prerequisite test, the following results are obtained:

a. Normality test

The results of the normality test can be seen in the following table

Table 1. Normality Test Results

\begin{tabular}{|c|c|c|c|}
\hline Variables & Entrepreneurial Success & Planning & Business Record \\
\hline $\begin{array}{l}\text { Asymp. Sig. } \\
\text { (2-tailed) }\end{array}$ & 0,074 & 0,766 & 0,290 \\
\hline
\end{tabular}

From the table above, it is known that each variable has an Asymp value. Sig. (2tailed) above $=0.05$ so that the three variables are declared normally distributed. 
b. Multicollinearity Test

Based on the results of the multicollinearity test, the tolerance value for each independent variable is the planning variable and the business record variable with a value of 0.996 greater than 0.10 , so it is stated that there are no symptoms of multicollinearity in the regression model.

c. Heteroscedasticity test

Based on the results of the heteroscedasticity test, a significant value was obtained on the planning variable $=0.559$ and the business record variable $=0.519$, which is greater than $=0.05$, so it is stated that there is no heteroscedasticity symptom in the regression model.

3. Regression Equation Analysis, t Test and F Test

Table 2. Multiple Linear Regression Test Results t test

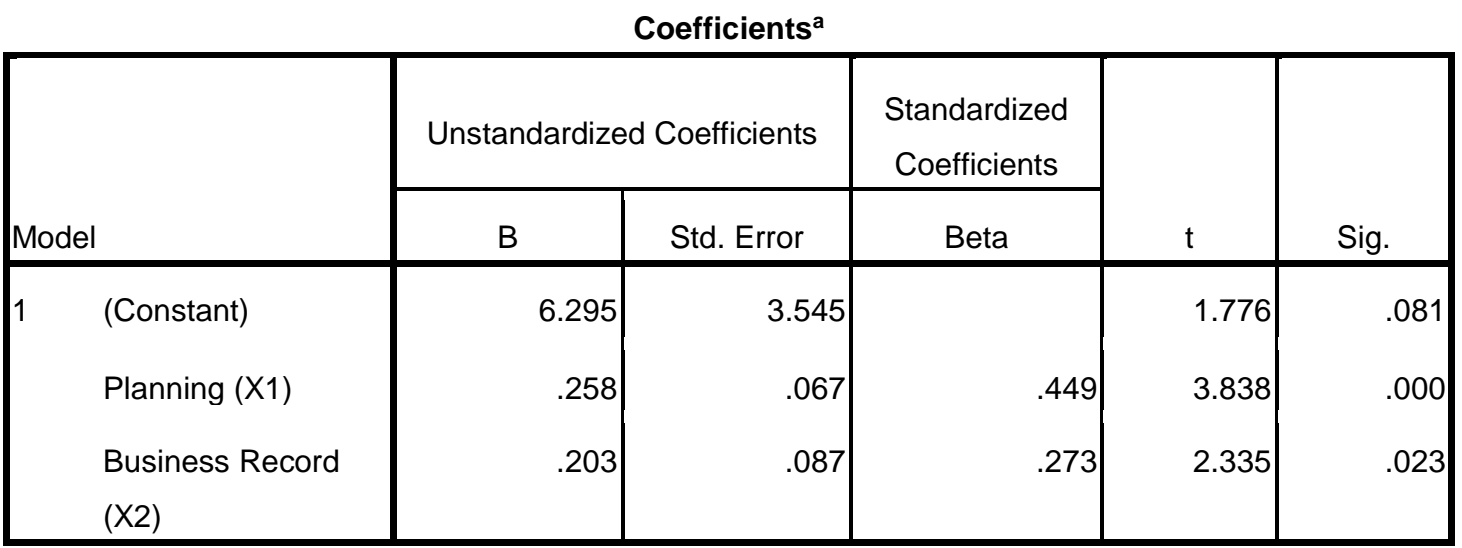

a. Dependent Variable: Entrepreneurial Success $(\mathrm{Y})$

Based on the table above, it can be seen that the multiple linear regression equation is $\mathrm{Y}=6.295+0.258 \mathrm{X}_{1}+0.203 \mathrm{X}_{2}$ so that from this equation it can be interpreted that the better the planning and business records, the higher the success of entrepreneurship. Furthermore, from the table it is also known that through the t-test, the $t_{\text {count }} X_{1}=3.838$, the $t_{\text {count }} X_{2}=2.335$ is greater than $t_{\text {table }}=2.004$ so it can be stated that business planning and records have a partial positive effect on entrepreneurial success. After obtaining the results of the regression equation and test, then an analysis of the F test is carried out which can be seen in the following table:

Table 3. F Test Results

ANOVA $^{\mathrm{b}}$

\begin{tabular}{|c|c|c|c|c|c|c|}
\hline \multicolumn{2}{|c|}{ Model } & Sum of Squares & df & Mean Square & $\mathrm{F}$ & Sig. \\
\hline \multirow[t]{3}{*}{1} & Regression & 116.190 & 2 & 58.095 & 9.600 & $.000^{\circ}$ \\
\hline & Residual & 326.792 & 54 & 6.052 & & \\
\hline & Total & 442.982 & 56 & & & \\
\hline
\end{tabular}

a. Predictors: (Constant), Business records, Planning

b. Dependent Variable: Entrepreneurial Success

Based on the results of the $\mathrm{F}$ (simultaneous) test as shown in table 3 above, it is known that the value of Fcount $=9.6$ is greater than Ftable $=3.17$ so that it can be stated that 
business planning and records have a simultaneous positive effect on entrepreneurial success. The coefficient of determination is obtained $=0.262$ so it can be stated that the magnitude of the influence of the planning variable and business records on entrepreneurial success is $26.2 \%$ and the remaining $73.8 \%$ is influenced by other factors.

Based on the results of the statistical tests described above, it can be explained that everyone wants success in life, including success in entrepreneurship. A person's success in entrepreneurship can be seen from the development of the capital owned or assets owned by the entrepreneur so that based on this it can be interpreted that the success of entrepreneurship is a person who is able to develop capital or assets from before. Entrepreneurial success is not as easy as many people think because to achieve this requires a long struggle or a very hard challenge and several things need to be considered in order to achieve success in entrepreneurship. The capital and assets that develop start from good planning before starting a business as well as after running the business and also recording all business activities. An entrepreneur who makes plans when running his business, the entrepreneur can plan a new strategy for the business, plan new innovations to attract the attention of the community as consumers. Through planning, an entrepreneur can make his business from a small business to a bigger one and can even become a successful entrepreneur.

Business planning is a process that will be carried out in the future to achieve the goals set by the entrepreneur. This is important because the planning of the business that will be run or is being run is a work guideline. In general, small and medium-sized and even largescale business plans manage the processes of business activities, marketing, sales, development, finance, purchasing, supplying and even the required manpower.

Based on the data obtained, it is known that the entrepreneurs who become research respondents in Tanjung Rejo Village who do not have good planning when going to run a business and when running a business more entrepreneurs do not experience an increase in business and vice versa entrepreneurs who have planning before and after Entrepreneurship has increased in the form of capital or business assets. This also illustrates that planning has benefits for every business person.

Therefore, individuals will not be able to develop themselves if they do not use the ability to think to create something new in order to be able to change their lives through entrepreneurship that starts with business planning. Many people think that entrepreneurship in the age of sophisticated technology will not be able to achieve success. In fact, according to Basrowi (2011) that the benefits of entrepreneurship include providing role models to the surrounding community as individuals who are exemplary from the results of hard work, perseverance, patience and even if seen as citizens they can help the government reduce unemployment and can improve the economy even though the scale is still small. small. Based on this, an entrepreneur who has a good plan is someone who is able to make a business plan that will be run, the capital needed, the location of the business, the targets to be achieved and the development of the business.

In addition to planning, business records can also affect the success of entrepreneurship where based on the results of data analysis it is obtained that business records affect the success of entrepreneurship. By looking at these results, it can be seen that business records have an important role in managing a business that is being run because through recording, an entrepreneur can know every activity and development of his business. From the data obtained, it is known that entrepreneurs in Tanjung Rejo Village who do not have business records when running a business are more entrepreneurs who do not experience an increase in business and vice versa entrepreneurs who have business records in entrepreneurship succeed in achieving what the entrepreneur wants. The most important 
business records are about the financial statements of the business being run in addition to recording incoming goods and outgoing goods and other records. If the entrepreneur has a good business record, it is very likely that the entrepreneur can develop the business by borrowing capital from the bank. It is well known that the bank will provide a loan if it has business activities in the form of financial statements or other business records so that from the recording it can be analyzed the ability of entrepreneurs to repay their loans to the bank.

\section{CONCLUSION}

From the explanation above, it can be concluded that business planning and records have an effect on entrepreneurial success. The better the planning carried out by business people, the higher the level of entrepreneurial success. Likewise in terms of recording that the better the business record, the higher the level of entrepreneurial success. Based on this, it is expected that business people, especially Micro, Small and Medium Enterprises or the public in general who want to depend on their life in entrepreneurship must have good planning and have good records when running their business.

\section{REFERENCES}

Basrowi, (2011). Kewirausahaan Untuk Perguruan Tinggi. Bogor: Ghalia Indonesia

Hendro. (2011). Dasar-Dasar Kewirausahaan. Jakarta : Erlangga

Tambunan, Formaida, (2020). Pengaruh Adversity Quotient Terhadap Kesuksesan Berwirausaha (Studi Empiris Pada Wirausahaan Di Kelurahan Tanjung Rejo Kecamatan Medan Sunggal). JUPIIS: Jurnal Pendidikan Ilmu-Ilmu Sosial, Vol 12, No 1 (2020).

Tambunan, Formaida, (2018). Pengaruh Percaya Diri dan Tekad Yang Kuat Terhadap Berwirausaha. Jurnal Administrasi Publik, Vol.8(2) Desember 2018

Wiratna dan Tambunan, Formaida, (2017). Pengaruh Peran Orangtua Sebagai Pendiri Terhadap Keberhasilan Wirausaha Di Kelurahahan Helvetia Tengah Medan Tahun 2017. Jurnal At-Tawassuth, Vol. II, No. 22017 